Research.

\title{
The influence of job motivation and work environment upon job performance of the employees of trade and industry office in Bogor district
}

\author{
Sumardjono \\ Department of Management, Economic College of Binaniaga, Bogor, Indonesia \\ sdjonref18@gmail.com \\ Rizki Adiatama \\ Department of Management, Economic College of Binaniaga, Bogor, Indonesia
}

Received: July 25, 2019; Accepted: August 12, 2019; Published: December 31, 2019

To cite this article: Sumardjono, Rizki Adiatama. 2019. The Influence of Job Motivation and Work Environment upon Job Performance of The Employees of Trade and Industry Office in Bogor District. The Management Journal of BINANIAGA. 4 (2): 55-64. doi: 10.33062/mjb.v4i2.336

\begin{abstract}
This study aims to explain the effect of job motivation and work environment upon job performance of the employees of Trade and Industry Office in Bogor District. The analytical instrument used in this study is Multiple Linear Regression which is first test using validity and reliability tests. The data analysis technique used in this study is using SPSS 22.0 computer statistical software. The sampling method taken is 121 respondents. The results of this study indicate that Job Motivation has a significant effect on job performance of the employees of (Dinas Perdagangan dan Perindustrian Kabupaten Bogor) Trade and Industry Office in Bogor District, Work Environment has no significant effect on the job performance of the employees of Trade and Industry Office in Bogor District. Job Motivation and Work Environment simultaneously does not affect job performance of the employees of Trade and Industry Office in Bogor Office.
\end{abstract}

Keywords: Job Motivation, Work Environment, Employees Job Performance

\section{Introduction}

\section{Background}

One of the factors influencing the improvement of job performance is motivation. Motivation is an individual willingness to act. As a matter of fact, human action is to fulfil his needs.

Hasibuan quoted in Danang (2012:191) declared that motivation is "a trigger driving someone to move and each motive of the people has their own goal to reach".

Job performance of the employees is not only influenced by motivation, but also influenced by working environment (Siagian, 2013:87). Unhealthy condition of working environment will make the employees easily depressed, they do not have the spirit of working, and they are accustomed to coming late. But on the contrary, healthy working environment will make the employees full of spirit to work, healthy,easy concentrate to their job, can complete their job on time and reach the target.

Working environment has two dimensions, physical dimension (colour of working area, lighting, cleanliness, space design, etc.) and non physical dimension (employees welfare, working atmosphere, employees interpersonal relationship with each other, etc) . An organization should have provided both dimensions good to make the employees

Sumardjono and Rizki Adiatama. The Influence of Job Motivation and Work Environment upon Job Performance of The Employees of Trade and Industry Office in Bogor District 
willingly working productively and working in a team either with their peers or their managers to reach the organization goals.

\section{Objectives of the Research}

This research aims to :

1. To recognize the extent of which motivation has affected job performance of the employees of Trade and Industry Office in Bogor District.

2. To recognize the extent of which work environment has affected job performance of the employees of Trade and Industry Office in Bogor District.

3. To recognize the extent of which motivation and work environment simultaneously has affected job performance of the employees of Trade and Industry Office in Bogor District.

\section{Library Review}

\section{Job Performance}

Mangkunegara (2013:67) described that job performance is the quality and quantity of job result achieved by an employee to perform his jobs according to his responsibility given. According to Marwasyah (2012:124), job performance is an achievement of an employee related to his/her tasks given to be executed. Hasibuan (2010:94) offered another opinion, it is a sacrifice of the service physically, an idea to produce the goods or services to get a reward for what he/she is doing.

\section{Motivation}

According to the etimology of motivation, it is coming up from latin words means motivus or motum which means to drive or to move. Based on this etimology, Lorens Bagus in Phylosophy dictionary, describing that motivation or motive is an awareness of driving action to determine people having a specific requirement.

\section{Working Environment}

Ahsyari (2012:109) describing that working environment is every thing surrounding employees which can influence them doing their jobs. Sedarmayanti (2012:21) mentioned, work environment is an instrument and a place where people are working which is jobs method, works schedule either individual or a team. Tohardi (2012:126), work environment is an environment where the employees are doing their jobs and tasks every day.

\section{Previous Research}

M. Zainal Abidin (2013), The Effect of Motivation and Work Environment upon Job Performance of the employees at Training and Education and Research and Development Office in East Kutai District. Result of the research indicated that job motivation and work environment had affected significantly job performance of the employee. Aldo Herlambang Gardjito (2014), The Effect of Job Motivaion and Work Environment upon Job Performance of the Employees (the study about the employees who had worked in the Production at PT Karmand Mitra Andalan Surabaya). The research had applied Multiple Linear Regression Analysis. Result of the research indicated Job Motivation and Work Environment had affected significantly Job performance of the employees, and Job Motivation and Work Environment simultaneously had significantly affected Job Performance of the Employees.. Cynthia Novia Hidayat (2015), The Effect of Work Environment and Job Motivation upon Job Performance of the Employees at the office of PT Keramik Diamond Industries. The research had applied Multiple Linear Regression Analysis and the result of the research

Sumardjono and Rizki Adiatama. The Influence of Job Motivation and Work Environment upon Job Performance of The Employees of Trade and Industry Office in Bogor District 
indicated that Work Environment and Job Motivatiion had affected significantly Job Performance of the Employees. However, Job Motivation had mostly affected Job Performance. Dewa Putu Meles Arta, Ni Ketut Lisna Deni Sari (2015), The Effect of Motivation and Work Environment upon Job Performance of Government Employees in the Office of Customs and Excises Medium Type Ngurah Rai Badung district. The research had applied Multiple Linear Regression Analysis. The research indicated that Job Motivation and Work Environment had significantly affected Job Performance of the employees, and Job Motivation and Work Environment simultaneously had affected significantly Job Performance of the employees. Jefika Dwi Ariyani (2017), The Influence of Job Performance and Work Environment upon Job Performance of the employees of Public Works Service and Mineral Resources Energy Service in Magelang District. Method of the research had applied Multiple Linear Regression Analysis. The research resulted that Work Environment did not affect significantly job performance of the employes because the working place had been considered good refered to the value of significance of frequency. However, job motivation had affected positively and significantly job performance of the employees refered to determinant coefficient value of $11.7 \%$ describing changes of employees' job performance.

\section{Research Design}

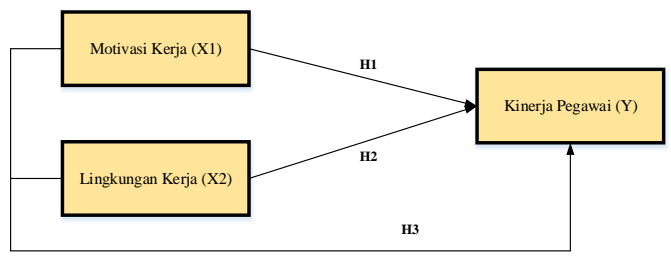

Drawing of Reseach Design

(Job motivation (X1); Work Environment (X2); Job Performance of employees(Y)

\section{Methodology of The Research}

\section{Operational Variables}

This research has 3 variables, job motivation, work environment and job performance of the employees of Trade and Industry Office in Bogor District.

1. Independent Variables

This research has two independent variables, Job Motivation (X1) and Work Environment (X2)

2. Dependent Variable

Job Performance of the employee $(\mathrm{Y})$ is a dependent variable.

\section{Technics of Data Analysis}

1. Validity and Reliability Test

2. Descriptive Analysis

3. Classic Assumption Test

4. Coefficient of Correlation Test

5. Hypotheses Test

Sumardjono and Rizki Adiatama. The Influence of Job Motivation and Work Environment upon Job Performance of The Employees of Trade and Industry Office in Bogor District 


\section{Result and Description}

\section{Test Result}

\section{Normality Test}

Output of Normality Test

\begin{tabular}{|l|l|r|}
\hline \multicolumn{2}{|c|}{ One-Sample Kolmogorov-Smirnov Test } \\
\hline $\mathrm{N}$ & Unstandardized & Predicted \\
\hline \multirow{2}{*}{ Normal Palue } \\
\hline \multirow{3}{*}{ Most Extreme Differences } & Mean & 121 \\
\cline { 2 - 4 } & Std. Deviation & 37.9504132 \\
\cline { 2 - 3 } & Absolute & .69600283 \\
\cline { 2 - 3 } & Positive & .072 \\
\cline { 2 - 3 } & Negative & .062 \\
\hline Test Statistic & & .072 \\
\hline Asymp. Sig. (2-tailed) & .072 \\
\hline
\end{tabular}

Source: Primary data processed, 2019

\section{Linearity Test}

Output of linearity test of Job Motivation Variable (X1)

\begin{tabular}{|c|c|c|c|c|c|c|c|}
\hline \multicolumn{8}{|c|}{ ANOVA Table } \\
\hline & & & $\begin{array}{l}\text { Sum of } \\
\text { Squares }\end{array}$ & $d f$ & $\begin{array}{l}\text { Mean } \\
\text { Square }\end{array}$ & $\mathrm{F}$ & Sig. \\
\hline \multirow[t]{5}{*}{ Total $(Y){ }^{*}$ Total $(\mathrm{X} 1)$} & \multirow{3}{*}{$\begin{array}{l}\text { Between } \\
\text { Groups }\end{array}$} & (Combined) & 680.278 & 21 & 32.394 & 4.572 & .000 \\
\hline & & Linearity & 48.378 & 1 & 48.378 & 6.828 & .010 \\
\hline & & $\begin{array}{l}\text { Deviation from } \\
\text { Linearity }\end{array}$ & 631.900 & 20 & 31.595 & 4.459 & .000 \\
\hline & \multicolumn{2}{|c|}{ Within Groups } & 701.424 & 99 & 7.085 & & \\
\hline & \multicolumn{2}{|l|}{ Total } & 1381.702 & 120 & & & \\
\hline
\end{tabular}

Resource: Primary Data processed, 2019

Output of Linearity test of Work Environment Variable (X2)

\begin{tabular}{|c|c|c|c|c|c|c|c|}
\hline \multicolumn{8}{|c|}{ ANOVA Table } \\
\hline & & & $\begin{array}{c}\text { Sum of } \\
\text { Squares }\end{array}$ & df & $\begin{array}{l}\text { Mean } \\
\text { Square }\end{array}$ & $\mathrm{F}$ & Sig. \\
\hline \multirow{5}{*}{$\begin{array}{l}\text { Total (Y) } \\
\text { * Total } \\
(\mathrm{X} 2)\end{array}$} & \multirow{3}{*}{\begin{tabular}{|l} 
Between \\
Groups
\end{tabular}} & (Combined) & 657.885 & 16 & 41.118 & 5.908 & .000 \\
\hline & & Linearity & 6.356 & 1 & 6.356 & .913 & .341 \\
\hline & & $\begin{array}{l}\text { Deviation from } \\
\text { Linearity }\end{array}$ & 651.529 & 15 & 43.435 & 6.241 & .000 \\
\hline & \multicolumn{2}{|c|}{ Within Groups } & 723.817 & 104 & 6.960 & & \\
\hline & \multicolumn{2}{|l|}{ Total } & 1381.702 & 120 & & & \\
\hline
\end{tabular}

Source : Primary Data processed, 2019 


\section{Multicolinearity Test}

Output of Multicolinearity Test

\begin{tabular}{|c|c|c|}
\hline \multicolumn{3}{|c|}{ Coefficients $^{a}$} \\
\hline \multirow[b]{2}{*}{ Model } & \multicolumn{2}{|c|}{ Collinearity Statistics } \\
\hline & Tolerance & VIF \\
\hline \multirow{3}{*}{$\begin{array}{l}\text { (Constant) } \\
\text { Total (X1) } \\
\text { Total (X2) }\end{array}$} & & \\
\hline & .993 & 1.007 \\
\hline & .993 & 1.007 \\
\hline \multicolumn{3}{|c|}{ a. Dependent Variable: Total (Y) } \\
\hline
\end{tabular}

\section{Heteroscedasticity Test}

Output of Heteroscedasticity Test

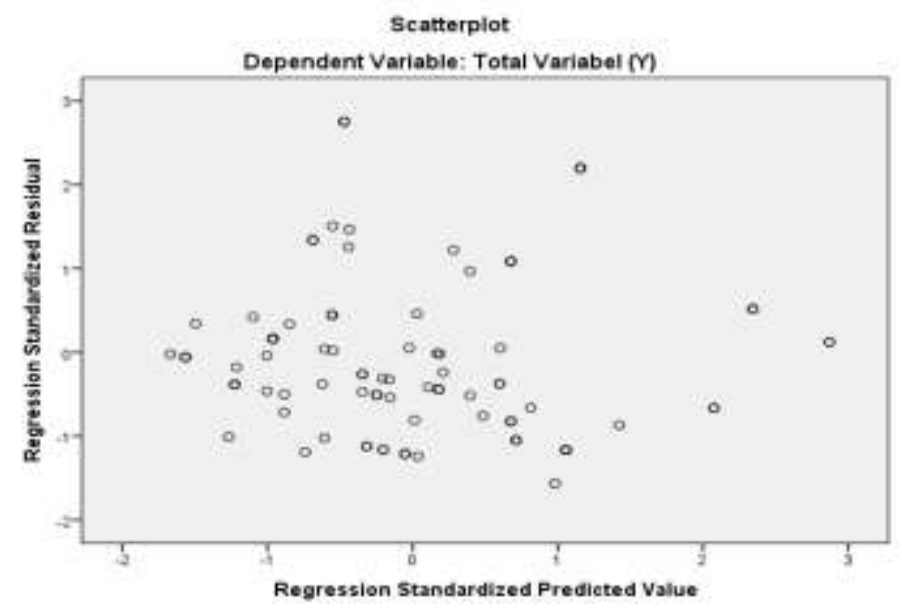

2019 Source :Primary Data processed, 2019

\section{Coefficient of Correlation Test}

Output of Correlation Analysis

\begin{tabular}{|c|c|c|c|c|}
\hline \multicolumn{5}{|c|}{ Correlations } \\
\hline & & Total $(\mathrm{X} 1)$ & $\overline{\text { Total }(\mathrm{X} 2)}$ & Total $(\mathrm{Y})$ \\
\hline \multirow[t]{3}{*}{ Total (X1) } & Pearson Correlation & 1 & -.085 & $.187^{*}$ \\
\hline & Sig. (2-tailed) & & .355 & .040 \\
\hline & $\mathrm{N}$ & 121 & 121 & 121 \\
\hline \multirow[t]{3}{*}{ Total (X2) } & Pearson Correlation & -.085 & 1 & .068 \\
\hline & Sig. (2-tailed) & .355 & & .460 \\
\hline & $\mathrm{N}$ & 121 & 121 & 121 \\
\hline \multirow[t]{3}{*}{ Total (Y) } & Pearson Correlation & $.187^{*}$ & .068 & 1 \\
\hline & Sig. (2-tailed) & .040 & .460 & \\
\hline & $\mathrm{N}$ & 121 & 121 & 121 \\
\hline
\end{tabular}

Source : Primary data processed, 2019 
The Management Journal of BINANIAGA Vol. 04, No. 02, December 2019

p-ISSN: $2527-4317$, e-ISSN: $2580-149 x$

$6^{\text {th }}$ Accreditation Rating: April 04, 2019- April 03, 2024

\section{Analysis Test of Multiple Linear Regression}

Output of the Test of Multiple Linear Regression Analysis

\begin{tabular}{|c|c|c|c|c|c|}
\hline \multicolumn{6}{|c|}{ Coefficients $^{a}$} \\
\hline \multirow[b]{2}{*}{ Model } & \multicolumn{2}{|c|}{$\begin{array}{l}\text { Unstandardized } \\
\text { Coefficients }\end{array}$} & \multirow{2}{*}{$\begin{array}{c}\text { Standardized } \\
\text { Coefficients } \\
\text { Beta }\end{array}$} & \multirow[b]{2}{*}{$\mathrm{t}$} & \multirow[b]{2}{*}{ Sig. } \\
\hline & B & Std. Error & & & \\
\hline \multirow{3}{*}{$\begin{array}{l}\text { Constant) } \\
\text { Total (X1) } \\
\text { Total (X2) }\end{array}$} & 33.849 & 2.219 & & 15.254 & .000 \\
\hline & .057 & .027 & .194 & 2.148 & .034 \\
\hline & .033 & .035 & .084 & .932 & .353 \\
\hline
\end{tabular}

The following Regression Equation is produced.

$$
Y=33.849+0,057 X 1+0,033 \times 2+e
$$

Referring to the Regression Equation above, the following interpretations have been coming up:

1. Constant value of 33.849 describing that if independent variables of Job Motivation and Work Environment are constant or are not changing, Job Performance of employees will increase 33.849.

2. Coefficient value of regression $\mathrm{X} 1=0.057$ describing that if Job Motivation of the employees of Trade and Industry Office in Bogor District is increased but work environment is constant (not any changes happened) Job Performance of the employees predictably will be increasing 0.057 .

3. Coefficient value of regression $\mathrm{X} 2=0.033$ explaining that if work environment of the employees of Trade and Industry Offce in Bogor district is increased more but job motivation variable is constant (no changes), it is predictable that Job Performance of the emplloyees wil be increasing 0.033 .

\section{T-test Result}

Output of T-test

\begin{tabular}{|c|c|c|c|c|c|}
\hline \multicolumn{6}{|c|}{ Coefficients $^{\mathrm{a}}$} \\
\hline \multirow[b]{2}{*}{ Model } & \multicolumn{2}{|c|}{$\begin{array}{l}\text { Unstandardized } \\
\text { Coefficients }\end{array}$} & \multirow{2}{*}{$\begin{array}{c}\begin{array}{c}\text { Standardized } \\
\text { Coefficients }\end{array} \\
\text { Beta }\end{array}$} & \multirow[b]{2}{*}{ t } & \multirow[b]{2}{*}{ Sig. } \\
\hline & $\mathrm{B}$ & Std. Error & & & \\
\hline \multirow{3}{*}{$\begin{array}{l}\text { (Constant) } \\
\text { Total (X1) } \\
\text { Total (X2) }\end{array}$} & 33.849 & 2.219 & & 15.254 & .000 \\
\hline & .057 & .027 & .194 & 2.148 & .034 \\
\hline & .033 & .035 & .084 & .932 & .353 \\
\hline
\end{tabular}

Source: Primary Data processed, 2019

Test output has indicated that $t_{\text {count }}$ of Job Motivation of 2.148 and Work Environment of 0.932 . $T_{\text {table }}$ of 1.9801 . $T_{\text {table }}$ value indicated on the $t$ distribution table to test two distributions which is on the column of 0.05 or (5\%) and on line 119 (total of 121 data minus total of 2 independent variables). Output of T test as follows:

1. Tcount Job Motivation variable is $2.148>$ table of 1.9801 , Ho is rejected and Job Motivation has affected significantly Job Performance.

2. $\mathrm{T}_{\text {count }}$ of Work Environment variable of $0.932<\mathrm{t}$ table of 1.9801 , Ho is accepted. Nevertheless, Work Environment did not affected significantly Job Performance.

Sumardjono and Rizki Adiatama. The Influence of Job Motivation and Work Environment upon Job Performance of The Employees of Trade and Industry Office in Bogor District 


\section{Hypothesis F Test}

Output of Hypothesis F test

\begin{tabular}{|l|r|r|r|r|c|}
\hline \multicolumn{7}{|c|}{ ANOVA $^{\mathrm{a}}$} \\
\hline Model & Sum of Squares & \multicolumn{1}{|c|}{ df } & Mean Square & F & Sig. \\
\hline Regression & 58.130 & 2 & 29.065 & 2.591 & $.079^{\mathrm{b}}$ \\
\hline Residual & 1323.572 & 118 & 11.217 & & \\
\hline Total & 1381.702 & 120 & & & \\
\hline a. Dependent Variable: Total (Y) \\
b. Predictors: (Constant), Total (X2), Total (X1) \\
\hline
\end{tabular}

Table above has indicated $F_{\text {count }}$ of 2.591. But $F_{\text {table }}$ of 3.07 , mentionned on the table of $\mathrm{F}$ distribution (Table $\mathrm{F}$ attachment), on column 2 (total all variables of 3 minus 1 dependent variable), on line 118 (total of 121 data minus 3 dependent variables)

$F_{\text {count }} 2.591<F_{\text {table }} 3.07$, Ho is accepted but $\mathrm{Ha}$ is rejected, it has been explaining that Job Motivation and Work Environment simultaneously did not affect significantly Job Performance. On the table above indicating that Sig. value of $0.079,0.05<$ sig. 0.079 , $\mathrm{Ho}$ is accepted and $\mathrm{Ha}$ is rejected, it has explained that Job Motivation and Work Environment simultaneously did not affect significantly Job Performance.

\section{Determinant Coefficient}

Output of Determinant Coefficient Test

\begin{tabular}{|l|c|c|c|c|}
\hline \multicolumn{5}{|c|}{ Model Summary $^{\mathrm{b}}$} \\
\hline Model & $\mathrm{R}$ & $\mathrm{R}$ Square & Adjusted R Square & $\begin{array}{c}\text { Std. Error of the } \\
\text { Estimate }\end{array}$ \\
\hline 1 & $.205^{\mathrm{a}}$ & .042 & .026 & 3.349 \\
\hline a. Predictors: (Constant), Total (X2), Total (X1) \\
\hline b. Dependent Variable: Total (Y) \\
Source : Primary Data processed, 2019
\end{tabular}

Based on the determinant coefficient indicated on Adjustment R Square of 0.026, it has explained that the effort of Job Motivation and Work Environment has been affecting 2.6\% Job Performance of the employees of Trade and Industry Office in Bogor district, but $97.4 \%(100 \%-2.6 \%)$ of Job Performance of the Employees of Trade and Industry Office in Bogor District has been described by other factors instead of Job Motivation and Work Environment.

\section{Conclusion and Suggestions}

\section{Conclusion}

a. Job Motivation has significantly influenced Job Performance of the Employees of Trade and Industry Office in Bogor District. It is refered to the test result of $t_{\text {count }}$ of $2.148>$ table of 1.9801 .

b. Work Environment did not influence Job Performance of the Employees of Trade and Industry Office in Bogor District which is refered to the test result of $t_{\text {count }}$ of $0.932<t_{\text {table }}$ of 1.9801 .

c. Job Motivation and Work Environment simultaneously did not influence Job Performance of the Employees of Trade and Industry Office in Bogor District. 


\section{Suggestions}

a. Refering to the result of the research at the Trade and Industry Office in Bogor District. Job Motivation has significantly affected Job Performance of the Employees of Trade and Industry Office in Bogor District. And refers to the feed-back of the questionnaires distributed to 121 respondents, the management or the Chief Officer of the Trade and Industry Office in Bogor District should have concerned more to improve their employees welfare by evaluating it with finance department to review their salary received and to advise the employees not only relying on their basic salary but also to create their own business. Instead of being concerned with the employees welfare, the management should have to be concerned also supporting their health better, it is not only being supported by BPJS but also by other private insurance company. In order to improve employees job motivation, the management should have appreciated the employees who have been doing their job excellent by announcing their achievement during periodical outdoor meeting so that the employees will realize that they are being appreciated and accepted. Nevertheless, either the management are in the office or not, their employees will be working full of spirit.

b. Besides of Job Motivation and Working environment at the Trade and Industry Office in Bogor District, another employee's feed-back to be paid attention is regarding windows condition which should have to be taken care furthermore such as to install the curtains to avoid direct sunlight coming through the windows which is disturbing people work. The management should have to be more concerned about bad air circulation such as smoking smell at place which makes people uncomfortable. Rehabilitazion of the office building will make the building beautiful, however, the construction execution should be done after working hours or during holiday so that people can work comfortably. Nevertheless, the management who is the chief officer of this office should have checked and re-studied the safety condition of the office and hired more securities to check better people coming in and out of the office either they are allowed or have permitted before.

c. Since this research is only using two variables, however, next researchers are advised to add more variables affecting job performance of the employees of Trade and Industry Office in Bogor District.

\section{References}

Atmojo, Noto. (2012). Faktor-faktor Yang Mempengaruhi Produktivitas Kerja, Bandung.

Aldo Herlambang Gardjito, 2014, Pengaruh Motivasi Kerja Dan Linguae Kerja Terhadap Kinerja Karyawan (Studi pada Karyawan Bagian Produksi PT. Karmand Mitra Andalan Surabaya) diambil dari Jurnal Administrasi Bisnis Universitas Brawijaya, Vol 13, No 1 (2014), ISSN 1978 - 726X

Badri Munir Sukoco, 2011, Manajemen Administrasi Perkantoran Modern, Penerbit : Erlangga

Badri Yatim. 2013, Sejarah Peradaban Islam Dirasah Islamiyah II Penerbit : Raja Grafindo Persada (Rajawali Perss) ISBN : 978-421-337-3. Edisi / Cet : Edisi 1 Cet 24 .

Bambang Juanda dan Junaidi, 2013, Ekonometrika Deret Waktu: Teori dan Aplikasi, Penerbit : IPB Press

Sumardjono and Rizki Adiatama. The Influence of Job Motivation and Work Environment upon Job Performance of The Employees of Trade and Industry Office in Bogor District 
Cynthia Novita Hidayat, 2015. Pengaruh Linguae Kerja Dan Motivasi Kerja Terhadap Kinerja Karyawan Kantor PT. Keramik Diamond Industries. Diambil dari Agora, Jurnal Mahasiswa Manajemen Bisnis, Vol 3, No 2 (2015), ISSN print: 1907-3011

Danang, Sunyoto. 2012. Manajemen Sumber Daya Manusia. Jakarta: PT Buku. Seru

Dewa Putu Meles Arta, Ni Ketut Lisna Deni Sari. 2015. Pengaruh Motivasi Dan Lingkungan Kerja Terhadap Kinerja Pegawai Negeri Sipil Pada Kantor Pengawasan Dan Pelayanan Bea Dan Cukai Tipe Madya Pabean Ngurah Rai Kabupaten Badung. Diambil dari Jurnal Juima Vol. 5 No. 1, Maret 2015 ISSN. 2337-9804

Ghozali, Imam. (2013). Aplikasi Analisis Multivariate dengan Program SPSS. Semarang: Badan Penerbit UniversitasDiponegoro.

Herman Sofyandi - Iwa Garniwa, 2014, Perilaku Organisasi, Graha IImu, Yogyakarta

Hasibuan, Malayu S.P. 2010. Manajemen Sumber Daya Manusia. Edisi Revisi. Bumi Angkasa. Jakarta

(2013). Manajemen Sumber Daya Manusia, Bumi Aksara.

Jakarta

Jefika Dwi Ariyani, 2017. Pengaruh Motivasi Kerja Dan Linguae Kerja Terhadap Kinerja Pegawai Di Dinas Pekerjaan Umum Dan Energi Sumber Daya Mineral Kabupaten Magelang, Diambil dari E-Journal Student UNY, Vol 6, No 2 (2017), ISSN-2549-5771

M. Zainal Abidin, 2013, Pengaruh Motivasi dan Lingkungan Kerja terhadap Kinerja Pegawai di Badan Diklat dan Litbang Kabupaten Kutai Timur. Diambil dari Jurnal Administrasi Reform, Vol.1 No.1, Januari-Maret 2013, ISSN 2164-4063

Mangkunegara, A.A. Anwar Prabu, 2013. Manajemen Sumberdaya Manusia, Remaja Rosdakarya, Bandung

2011. Manajemen Sumber Daya Manusia. Perusahaan. PT. Remaja Rosda Karya, Bandung

Marwansyah. (2012). Manajemen Sumberdaya Manusia, Edisi Kedua, Bumi Angkasa. Jakarta

2016, Manajemen Sumber Daya Manusia. Edisi Dua. Cetakan keempat. Bandung: Alfabeta,CV

Pasolong. (2010). Pengaruh Insentif Terhadap Kinerja Karyawan, Jakarta: Gramedia Pustaka Utama

Rivai, Veithzal. 2011. Manajemen Sumber Daya Manusia Untuk Perusahaan. Dari Teori ke Praktik. Jakarta: Raja Grafindo Persada

Samsudin, Sadili. 2010. Manajemen Sumber Daya Manusia. Bandung : Pustaka Setia

Sedarmayanti, 2011. Manajemen Sumber Daya Manusia, Reformasi Birokrasi dan. Manajemen Pegawai Negeri Sipil (Cetakan Kelima). Bandung : PT Refika

2012. Manajemen Sumber Daya Manusia Reformasi Birokrasi dan Manajemen Pegawai Negeri Sipil, Bandung: Refika Aditama

Sumardjono and Rizki Adiatama. The Influence of Job Motivation and Work Environment upon Job Performance of The Employees of Trade and Industry Office in Bogor District 
The Management Journal of BINANIAGA Vol. 04, No. 02, December 2019

p-ISSN: $2527-4317$, e-ISSN: $2580-149 x$

$6^{\text {th }}$ Accreditation Rating: April 04, 2019- April 03, 2024

2013. Birokrasi dan Manajemen Pegawai Negri Sipil Manajemen Sumberdaya Manusia Reformasi, Refika Aditama, Bandung

Siangian, Sondang P. 2013. Manajemen Sumberdaya Manusia, Bumi Angkasa. Jakarta.

Simamora, Henry. (2015). Manajemen Sumber Daya Manusia. Edisi Ketiga. Yogyakarta: YKPN.

Sofyandi, Garniwa (2014). Manajemen Sumber Daya Manusia, Jakarta: Erlangga.

Sumadi Suryabrata, 2010, Psikologi Pendidikan, Penerbit: Jakarta: Raja Grafindo Persada

Sugiyono. (2010). Metode Penelitian Kuantitatif, Kualitatif dan R\&D. Alfabeta. Bandung. Bandung.

(2016). Metode Penelitian Kuantitatif, Kualitatif dan R\&D. Alfabeta.

Wirawan, 2012, Evaluasi Kinerja Sumber Daya Manusia Teori, Aplikasi, dan Penelitian, Penerbit : Salemba Empat

. (2013). Pengaruh Motivasi Terhadap Kinerja Karyawan Pada Direktorat Jenderal Pemasyarakatan Jakarta.

Sumardjono and Rizki Adiatama. The Influence of Job Motivation and Work Environment upon Job Performance of The Employees of Trade and Industry Office in Bogor District 